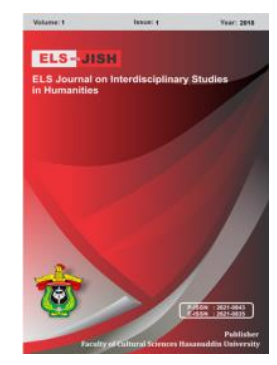

ELS-JISH

ELS Journal on Interdisciplinary Studies on Humanities

Volume 1 Issue 1, 2018

ISSN (print) : 2621-0843

ISSN (online) : 2621-0835

Homepage : http://journal.unhas.ac.id/index.php/jish

\title{
Applying Systemic Approach to Develop Students' Vocabulary
}

\author{
Andi Asdar ${ }^{1}$ \\ E-mail: aasdar47@yahoo.com
}

\begin{abstract}
Systemic approach in teaching vocabulary involved aspects in learning vocabulary. The aims of this research were to observe (1) the extent to which Systemic Approach develops students' vocabulary of the second semester of Makassar Islamic University; (2) the students' perceptions on the application of Systemic Approach in vocabulary development. This research was carried out with second semester students of Pharmacy Department, Faculty of Mathematics and Natural Sciences, Makassar Islamic University. The research method was quasi-experimental design with pre-test, eight meetings for treatment, and post-test. Data were collected with 2 instruments: vocabulary test and questionnaire, then analyzed with statistical analysis of sample $t$-test and questionnaire frequency. The result of the research indicated that the $p$ value of independent t-test comparing students' score on post-test was $p<0.05$. There was a significant difference between the students treated by systemic approach compared to those without systemic approach. The questionnaire analysis indicated that the students' perceptions on the application of Systemic Approach were positive.
\end{abstract}

Keywords: Systemic Approach, Vocabulary Development, Students' Perceptions

How to cite: Asdar, A. (2018). Applying Systemic Approach to Develop Students' Vocabulary. ELS-Journal on Interdisciplinary Studies in Humanities, 1(1), 90 - 95

\section{Introduction}

Teaching and learning are one of the essential processes in improving human resource. Regarding the teaching and learning of English, it is intended to emphasize students' capacities in acquiring this foreign language as a tool to provide a better access toward sciences and technology. Equally, some experts and scientists expand their horizon through English. Therefore, the students are demanded to acquire English in order to easily get knowledge and easily develop their knowledge.

The teaching of four language skills (reading, listening, writing and speaking) is determined by certain factors such as habit, student's strategies, material and teaching techniques. Weda (2007), pointed that the failure in English teaching and learning is caused by the students' strategies and the vocabulary mastery. He adds that some students can hardly comprehend the meaning of words from the reading without having high frequency level of vocabulary.

Acquiring high proficiency in English should be based on the vocabulary knowledge, for the reason that vocabulary competence is the key in acquiring all of the English

\footnotetext{
${ }^{1}$ State Islamic Institute of Samarinda 
language aspects (McKay, 2002). According to Xia (2010), vocabulary knowledge is great importance in expressing thought, attitude, and ideas in all language interaction activities. Therefore, lack of vocabulary mastery makes the students become dependent to their teachers.

Furthermore, Nagy (1983), mentioned the reasons why vocabulary instruction often fails to increase comprehension; they are "(1) vocabulary instruction fails to produce indepth word knowledge to indicate that reading comprehension requires high level of word knowledge higher than the level of achievement by many types of vocabulary instruction and (2) to improve reading comprehension relates to comprehensibility of text containing some unfamiliar words". Hence, the teachers should discover or find out some techniques to bring together the successful teaching and learning process, particularly teaching and learning vocabulary.

Nation (1990 a.), suggested that foreign language teacher should give awareness to the vocabulary teaching. He acknowledges that if we want to plan the vocabulary goal in long life education, at least we need three things to be learned; the amount of word in the language, the amount of word from the native speaker and the amount of word we will use in that language. Moreover, Nation (2001), classified the students' vocabulary level into four types: high frequency words, academic vocabulary, technical vocabulary, and low frequency words. For instance, the university students are focused on achieving at least the academic vocabulary and technical vocabulary.

English vocabulary teaching needs an appropriate strategy, as Nation (1990 b.), affirmed that if a teacher will help students handle with low frequency vocabulary, he is better to spend time to concentrate on vocabulary teaching strategies for dealing with unknown vocabulary by using available strategies. Differently, Wiese (2012), found that the use communicative approach in teaching ESP class, where teacher puts a list of words on the board and students write them and then look them up in the dictionary, and memorize them, has been not effective and students cannot acquire the vocabulary knowledge well.

Whereas, Tierney et al (1990), they acknowledged that teachers who have access to a repertoire of strategies that will support relevant vocabulary words, it is hoped to help students learn and keep words in long term memory. They declare the eight strategies such as possible sentences, list-group-label, contextual redefinition, preview in context, future analysis, systemic approach, vocabulary self-collection strategy, and key word method. Teacher can use these strategies in various aspects to promote the students' vocabulary development.

Moreover, vocabulary is central of language, it means that vocabulary is very important in language mastery because vocabulary as an element of language that regarded as the most important factor in increasing the mastery of the language skills. Vocabulary is the core of language mastery. It will be impossible for students to speak English without acquiring vocabulary. Hence, it is important to get students to make the best use of a small productive vocabulary. The students need to extend their productive vocabulary to include the specialized vocabulary of their areas of study and interest.

Having a good ability in communication is not easy. Sometimes students do not only feel afraid in communication with others, but they do not have a good command of vocabulary in their mind. So, they cannot communicate as clearly as they would like to say. Then, they tend to make mistake in conversation. Hence, they cannot express their ideas or opinions and converse to others. In developing students' vocabulary, they need 
an approach in enhancing vocabulary skill. Systemic Approach is one way in teaching vocabulary. The students cannot converse into sentences without understanding vocabulary.

By implementing systemic approach in the classroom, the students can be directly involved in the learning process because there are discussions, sharing among students, and they can learn independently. The other reason is this approach automatically supports Students-Centered Learning (SCL) which focuses more the students than lecturer.

Based on these facts, it is important to investigate the university students' strategy in acquiring vocabulary. In this research, the researcher presents systemic approach that involves aspects of words, such as; interaction, interrelation, and intersection of words as an approach in teaching vocabulary.

\section{Research Method}

\subsection{Research Design}

This research used quasi-experimental design with non equivalent control group design (Gay et al., 2006). There were two groups namely experimental and control group which received different treatments. The experimental group was treated by using systemic approach, while the control group was treated by conventional method. Pretest and posttest were administered for both control and experimental groups. The pretest was intended to find out the students' prior knowledge on vocabulary mastery; while posttest was used to measure the improvement of students' vocabulary after treatment. At the end, the results between the experimental group and control group were compared.

\subsection{Population and Sample}

The population of this research was the second semester students of Pharmacy Class of Makassar Islamic University in academic year 2015/2016. The total number of population was 160 students. The sample of this research was selected by cluster random sampling technique. The researcher took randomly two groups that represent as experimental and control group. The sample of this research was 80 students in which 40 students in experimental group and 40 students in control group.

\subsection{Method of Data Collection}

The researcher used two kinds of instruments to collect the data, those are vocabulary test and questionnaire. The vocabulary test was used to assess the students' learning achievement before and after receiving some treatments. After doing the posttest, the researcher distributed questionnaire in the last activity for experimental group. The questionnaire aimed to find out the students' perceptions during the process of teaching vocabulary by applying systemic approach.

In collecting the data, both groups were given pretest firstly. The aim of giving pretest was to find out the students' prior knowledge. The result of pretest was compared to the result of posttest which was given in the last meeting. Then, the treatment was given in eight meetings which delivered 90 minutes for each meeting. After conducting the treatment, both groups were given posttest to find out the students' achievement in vocabulary mastery. 


\subsection{Method of Data Analysis}

The data collected through vocabulary test were analyzed quantitatively using descriptive and inferential statistics by employing Statistical Product and Service Solution (SPSS) version 22 IBM for Windows. Then, the data from the questionnaire were classified into five points of rating scale by using the Likert Scale measurement.

\section{Findings}

Based on the result of the research, the students in experimental group and control group were in "fair level" of vocabulary mastery in the pretest which the mean score was 50.4 for experimental group and 51.75 for control group. However, in posttest, the experimental group performed better by gaining the mean score 70.15 that classified as "good level" than the control group that only gained the mean score 60.6 that classified as "fair level".

In output of Independent-sample t-test for pretest, the probability value 0.53 is higher than $\alpha=0.05$. This result means that there was no significant different in pretest between experimental and control group. Meanwhile, in output of Independent sample t-test for posttest, the result from the analysis indicated that there was significant different between experimental and control group with the probability value 0.000 is smaller than $\alpha=0.05$. Thus, the alternative hypothesis $(\mathrm{H} 1)$ is accepted. This finding concludes that there is a significant difference between vocabulary mastery of the students who are taught by applying systemic approach and those with conventional method.

Furthermore, the result of analyzing questionnaire revealed that applying systemic approach in developing students' vocabulary gained positive response from the students. It was also proven by the mean score of the students' perceptions which was classified as "Positive" by having the interval range $=60.5$.

\section{Discussion}

The result showed that there was a significant difference between vocabulary mastery of the students who are taught by applying systemic approach and those with conventional method. Systemic approach in teaching vocabulary involved aspects in learning vocabulary. Harmer (1991), pointed that learning vocabulary was a systemic process. In vocabulary learning, knowing a word involved knowing its form and knowing its meaning. In deeper aspects, it meant the ability to know the use and usage of the word. Generally, knowing a word involved knowing the formation of the word.

Systemic approach was a way in learning vocabulary. This way presented items of vocabulary building. Ur (1991 a.), stated that teaching vocabulary should involve a new item of vocabulary in more than a single word, for example, post office and mother-in-law. It was made up of two or three words but expressed a single idea. Hence, a useful convention was covering all such cases by talking about vocabulary 'items' rather than 'words'.

Moreover, Ur (1991 b.), indicated items of vocabulary that needed to be taught. First, form covered pronunciation and spelling. Pronunciation needed to be taught by English teachers because English words had inequality between written and oral words. Pronunciation was what a word sounds like and spelling was what it looks like. These were fairly obvious characteristics, and one or the other would be perceived by the learner when encountering the item for the first time. 
Second, grammar of a new item should be taught if this was not obviously covered by general grammatical rules. An item might have an unpredictable change of form in certain grammatical contexts or might have some idiosyncratic way of connecting with other words in sentences. Third, collocation was concerned with the way words occurred together. For example: You raise your hand to ask a question. The word of hand might be matched with raise or put no lift.

Fourth, aspect of meaning (1): denotation, connotation, and appropriateness. Denotation was the meaning of a word primarily what it referred to in the real word. This was often the sort of definition that was given in dictionary definition. Then, the more subtle aspect of meaning that often needed to be taught was whether a particular item of appropriate to use in certain context or not.

Sixth, aspect of meaning (2): meaning relationship. There were various such relationships, namely; synonyms, antonyms, hyponyms, and translation.

Seventh, word formation covered the word components. Such as prefix and suffix like sub-, un-, and able- (substandard, ungrateful, and untranslatable), and combination of two words like two nouns, or a gerund and a noun, or noun and a verb (bookcase, follow up, swimming pool).

Besides that, teaching vocabulary should be systemic, because it had certain rule. It also had subsystem such as: lexical subsystem, grammatical subsystem, and phonological subsystem (Sudaryat, 2008). Thus, Systemic approach was an approach in vocabulary learning. It involved all the subsystems in vocabulary teaching.

Therefore, as shown in this study, the researcher argued that in teaching vocabulary have to provide language teaching comprehensively. This meant that all criteria were involved, such as: interrelation (how do the words connect with each other?), intersection (do the words relevant with each other?), and interaction (do the words affect with each other?). So that, vocabulary was entire store of English words which were given to students in order they are able to use in reading, writing, listening, and speaking.

\section{Conclusion}

The application of systemic approach can improve students' vocabulary knowledge. Thus, the researcher deduces that systemic approach helps students at the basic competence in vocabulary development. Through systemic approach, the problem of students in developing vocabulary can be solved well. Moreover, the implementation of systemic approach is responded positively by the students. It is seen from the students' answers of agree and strongly agree which dominated the questionnaire. The students' perceptions describes that systemic approach helps the students in learning vocabulary. Systemic approach develops students' vocabulary knowledge and makes the learning more interesting. As mentioned previously, the findings of this study shows that systemic approach affects the students' vocabulary knowledge positively. However, there are some points need to be discussed; firstly, for the next researchers who are interested in vocabulary learning strategy. They have to understand the students need before giving them treatment in order to formulate suitable way of teaching. Secondly, it is important to investigate the vocabulary learning strategy and transfer vocabulary in long term memory. Thirdly, teaching English for non English department needs some experiences for the field. 


\section{References}

Gay L.R., Mills G.E. \& Airasian P. (2006). Educational Research; Competencies for Analyzing and Application ( $8^{\text {th }}$ edition). Pearson Merill Prentince Hall: New Jersey.

Harmer J. (1991). The Practice of English Language Teaching. London: Longman.

McKay S. L. (2002). Teaching English as an International Language. United Kingdom: Oxford University Press.

Nagy W. E. (1988). Vocabulary Instruction and Reading Comprehension. A Technical Report No, 431. Urbana Champaign: University of Illinois.

Nation I.S.P. (1990 a). Teaching Vocabulary. New Zealand: Victoria University of Wellington.

Nation I.S.P. (1990 b). Teaching and Learning Vocabulary. New York: Newbury House Publishers.

Nation I.S.P. (2001). Learning Vocabulary in Another Language. Cambridge: Cambridge University Press.

Sudaryat Y. (2008). Makna dalam Wacana, Prinsip-prinsip Semantik dan Pragmatik. Bandung: Yrama Widya.

Tierney R. J. et al. (1990). Reading Strategies and Practice. A Compendium. Third Edition. USA: Allyn and Bacon.

Ur P. (1991). A Course in Language Teaching, Practice, and Theory. Trainee Book. Cambridge University Press.

Weda S. (2007). English Learning Strategies. ISBN 978-979-16734-19. Makassar: LPPMM Press Makassar.

Wiese L. A. (2012). Analysis of Two Vocabulary Strategies; A Study to Indicate Which Strategy, Verbal and Visual Word Association or Contextual Redefinition, is Best Suited for Transferring New Words Into Students' Long Term Memory. Published Thesis, University of Wisconsin Superior.

Xia J. (2010). Communicative Language Teaching in Vocabulary Teaching and Learning in a Swedish Comprehensive Class. The School of Teacher Education. Kristiansand University. 